\title{
Managing seismicity at the Tasmania Mine
}

\author{
P.B. Hills $B C D$ Resources (Operations) NL, Australia
}

\begin{abstract}
Mining-induced seismicity was anticipated at the Tasmania Mine (formerly the Beaconsfield Gold Mine) prior to the commencement of modern production in 1999. Consideration of available stress measurement data from throughout Tasmania, coupled with rock material property data gathered at the Tasmania Mine during project feasibility investigations, suggested that onset of mining-induced seismicity could be expected at depth around $700 \mathrm{~m}$ below surface. That proved to be the case, with mining-induced seismicity regularly observed from $760 \mathrm{~m}$ and below from 2002.

Prior to 2006, management of seismicity was strictly controlled through geotechnical investigation and application of geotechnical control of all mining activities. The local stress regime was measured, understood and modelled in 2003. A temporary seismic monitoring system was operational from April 2004 and it was replaced with a permanent array in mid 2005. In late 2005, mining methods at the narrow vein Tasmania Mine were typical of mining methods employed at similar operations the world over. A substantial difference was the degree to which external opinion was sought, innovative techniques and methods were implemented, and a peer review of the entire process was undertaken. It wasn't enough: a seismically induced rockfall on 25th April (Anzac Day) 2006 took the life of a colleague. That the entire world was appraised of the accident was of secondary importance.
\end{abstract}

An extensive coronial investigation found that no corporation or individual erred in respect of the Anzac Day accident. The clear message from that finding was that generally acceptable techniques for the management of mining-induced seismicity, while at the limit of extant engineering experience, were below the expectations of the wider community.

Management of seismicity at the Tasmania Mine post Anzac Day is a multi-disciplinary activity that involves the entire workforce at every turn. Extensive seismic monitoring, saturation level instrumentation, development of innovative mining (and in particular stoping) methods, detailed 'first principals' ground support and reinforcement designs, exclusion and re-entry protocols surrounding all stope blasts, and the continued professional peer review of all geotechnical aspects of the operation, are part and parcel of the continued operation of the Tasmania Mine. This paper describes the latest developments in that process.

\section{Introduction}

In response to the Anzac Day rockfall, Workplace Standards Tasmania (WST) required the Tasmania Mine to eliminate or minimise the occurrence of seismic events as far as reasonably practicable. In the early 21st century, short of closing the mine, the elimination of seismicity was unlikely to occur. Nor did it. Figure 1 is a histogram of recorded seismicity at the Tasmania Mine covering the six year period from August 2005. It shows that the two most seismically active days in the mine's recorded history occurred after the resumption of production following the Anzac Day rockfall.

The WST request did result in an almost unprecedented work programme to determine the nature of seismicity at the Tasmania Mine and further develop the tools necessary to manage it. The initial outcome of the work programme, as specified by WST, was the development of a Case for Safety which was delivered in four parts between October 2006 and August 2007. The Case for Safety considered all aspects of safety related to underground operations at the Tasmania Mine, with a strong focus on matters related to geomechanics in general and the management of seismicity in particular. 


\section{Daily Histogram}

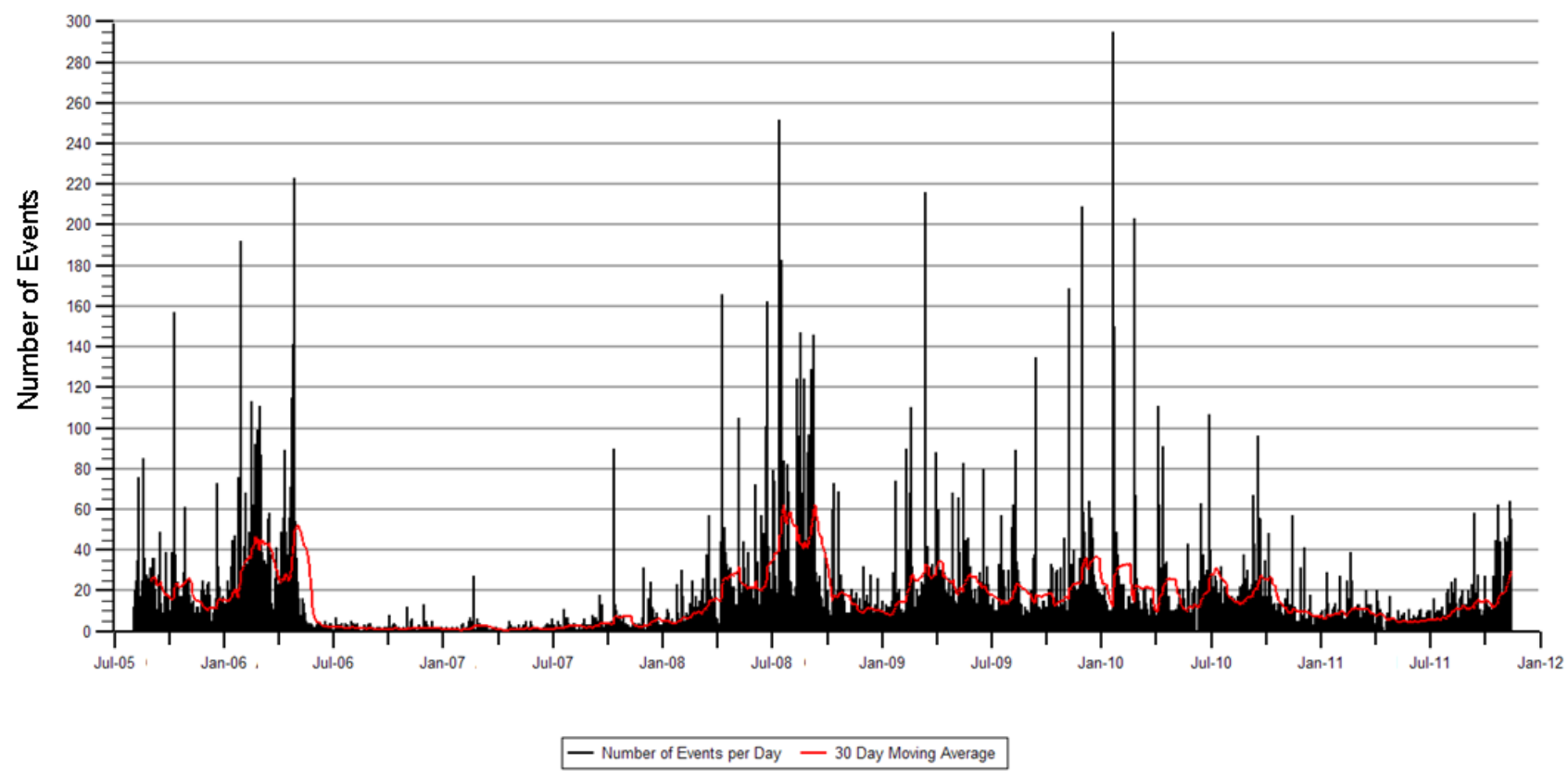

Figure 1 Histogram of seismicity at the Tasmania Mine, August 2005 - November 2011

The Case for Safety resulted in the development of a fully engineered approach to ground control in static and dynamic conditions, built on the work of Grimstad and Barton (1993) and Kaiser et al. (1996) in particular. Outcomes have included the development of site specific support and reinforcement protocols, the development of new mining methods for remote narrow vein mining, integration of geotechnical instrumentation with seismic monitoring and analysis, and the development of exclusion and re-entry protocols to manage seismicity. Numerous reports have been written, one thesis has been completed and a second one is pending, ten papers have been written, and several additional technical presentations have been given by Tasmania Mine staff and others. The purpose of this paper is to summarise what has occurred at the Tasmania Mine since 2006.

\section{The Tasmania Mine}

\section{1 Geological setting}

The Tasmania Mine is centred on a shear hosted vein style gold deposit of Victorian "slate belt" affinity, hosted within siliciclastic sediments of the Western Tasmanian geological terrane. The Denison Group siliciclastics, which host the Tasmania Reef, have been subdivided into the lower Salisbury Hill Formation, dominated by three significant conglomeratic horizons: the Cabbage Tree Conglomerate, the 2CG Conglomerate and the Wet Beds Conglomerate, separated by the 2SC and 1SC Sandstone and Conglomeratic Sandstone Members respectively. The overlying Eaglehawk Gully Formation comprises interbedded horizons of calcareous quartz sandstone, siltstone and stylolitic limestone. The relationship of the host rocks to the underlying and overlying stratigraphy is described by Hills et al. (2001).

The deposit is associated within a regime of thrust faulting and imbrication of the stratigraphy intra-thrust slice drag folding and the development of a series of transform shears exhibiting a predominantly dextral strike-slip sense of movement and dipping at around $50-70^{\circ}$ to the south-east. One such shear hosts the Tasmania Reef. Figure 1 illustrates the extant workings of the Tasmania Reef in relationship to the host rocks and related stratigraphy which generally dips to the northeast at $50^{\circ}$. Generally, the reef is widest where the contrasting rheology of juxtaposed hangingwall and footwall host rocks is greatest due to the dextral offset on the parent shear. Refraction of the Tasmania Reef shear around the axial planes of earlier 
intra-thrust slice drag folding has resulted in the focus of mineralisation being translocated $150 \mathrm{~m}$ east, below a depth of $1,000 \mathrm{~m}$ from surface.

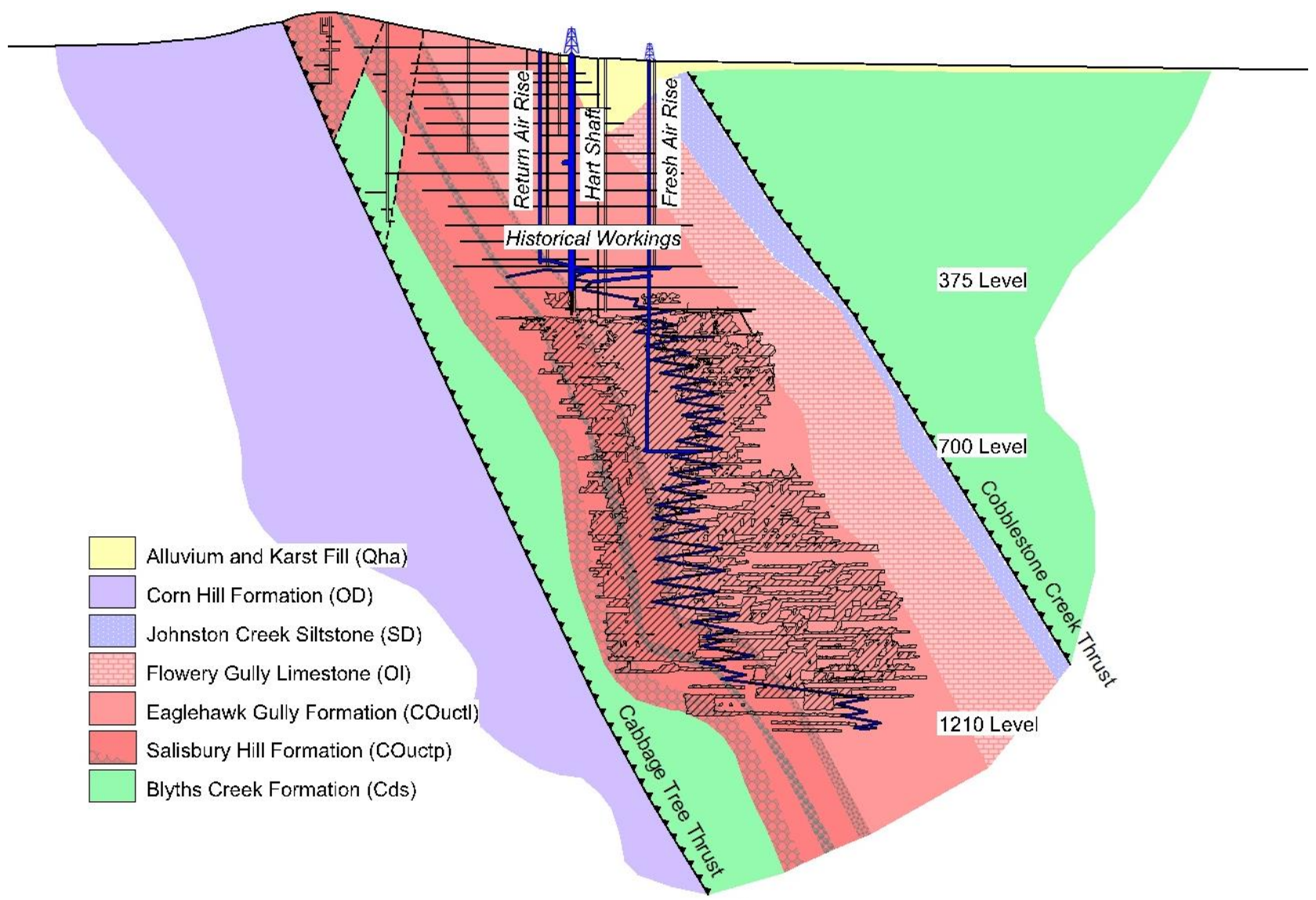

Figure 2 Longitudinal projection illustrating the extent of the Tasmania Mine workings relative to the hosting stratigraphy

While essentially a planar feature in a gross sense, the strike of the Tasmania Reef changes through $20-30^{\circ}$. Splay structures branch off the Tasmania Reef at various locations along the strike. Small faults orthogonal to the strike of the Tasmania Reef are common along its length. These faults usually propagate off bedding planes, commonly off shaley interbeds or at the contacts with the major conglomerate units. Offset of the reef on these nominally bedding parallel faults is almost invariably a few metres or less.

\section{2 Mining history}

The Tasmania Reef was discovered in 1877 and worked until 1914. During that period, mining progressed from surface outcrop to a depth of $455 \mathrm{~m}$ below the current shaft collar; a total vertical extent of $500 \mathrm{~m}$ when topography is considered. The early miners did not encounter mining induced seismicity. Rather, their operations were plagued by water ingress, refractory ore and industrial relations. The failure of the pumping system in November 1914, on the cusp of Australian involvement in World War 1, was the catalyst for an immediate cessation of operations.

After a long gestation period commencing in 1964, modern production commenced in 1999. In the period to 2011, the mine was extended from 455 Level to 1210 Level and production exceeding $2.5 \mathrm{Mt}$ recovered close to $900 \mathrm{koz}$ of gold. During the construction period of 1996-1999, the geotechnical focus of the operation was directed towards managing weak and deeply weathered rock conditions during the construction of two ventilation shafts, and developing critical infrastructure in a blocky rock mass where support systems were dominated by kinematic wedge analysis. Mining-induced seismicity was first observed at 760 Level, and has dominated geotechnical considerations since 2002. The Anzac Day rockfall 
led to a production hiatus from April 2006 until October 2007. The current life-of-mine schedule will see production cease in May 2012.

\section{3 Evolution of mining methods}

\section{3. 1 Preliminary and standard methods}

Geotechnical examination of diamond drill core during pre-production feasibility studies indicated that the hangingwall of the Tasmania Reef was going to be weak and prone to failure. Measurements of rock quality designation (RQD) rarely exceeded 25 . Consequently, mining commenced on the basis of using a flat-back cut-and-fill method over $25 \mathrm{~m}$ block heights in a generally top-down sequence.

In reality, ground conditions, and particularly those of the hangingwall, were better than predicted and the mining method quickly evolved to up-hole benching and ultimately modified Avoca stoping. Block heights increased to $38 \mathrm{~m}$. The bottom $4 \mathrm{~m}$ of each block was backfilled with cemented rock or cemented hydraulic fill to permit total extraction. Typically, a stoping block incorporated three sill drives over a height of $4.5 \mathrm{~m}$, and an up-hole bench of $4 \mathrm{~m}$ on the lowermost sill to facilitate the cemented fill pillar. Sill drives were separated by $7 \mathrm{~m}$ pillars which were subsequently extracted in Modified Avoca fashion.

With the onset of seismicity throughout 2004-2005, a number of changes to the mining method were implemented in an endeavour to mitigate the seismic impact. Those changes included increasing pillar thickness (ultimately to $13 \mathrm{~m}$ ), and incorporating a dynamic support and reinforcement regime. The latter incorporated the first use of modified cone bolts in Australia. The intent was to develop a system similar to the Rockburst Support System described by Falmange and Simser (2004). In a further development, the stoping sequence was altered to a checkerboard pattern, while maintaining the Modified Avoca stoping method, with the aim of maintaining a vertical rather than horizontal stoping front. The concept is illustrated in Figure 3.

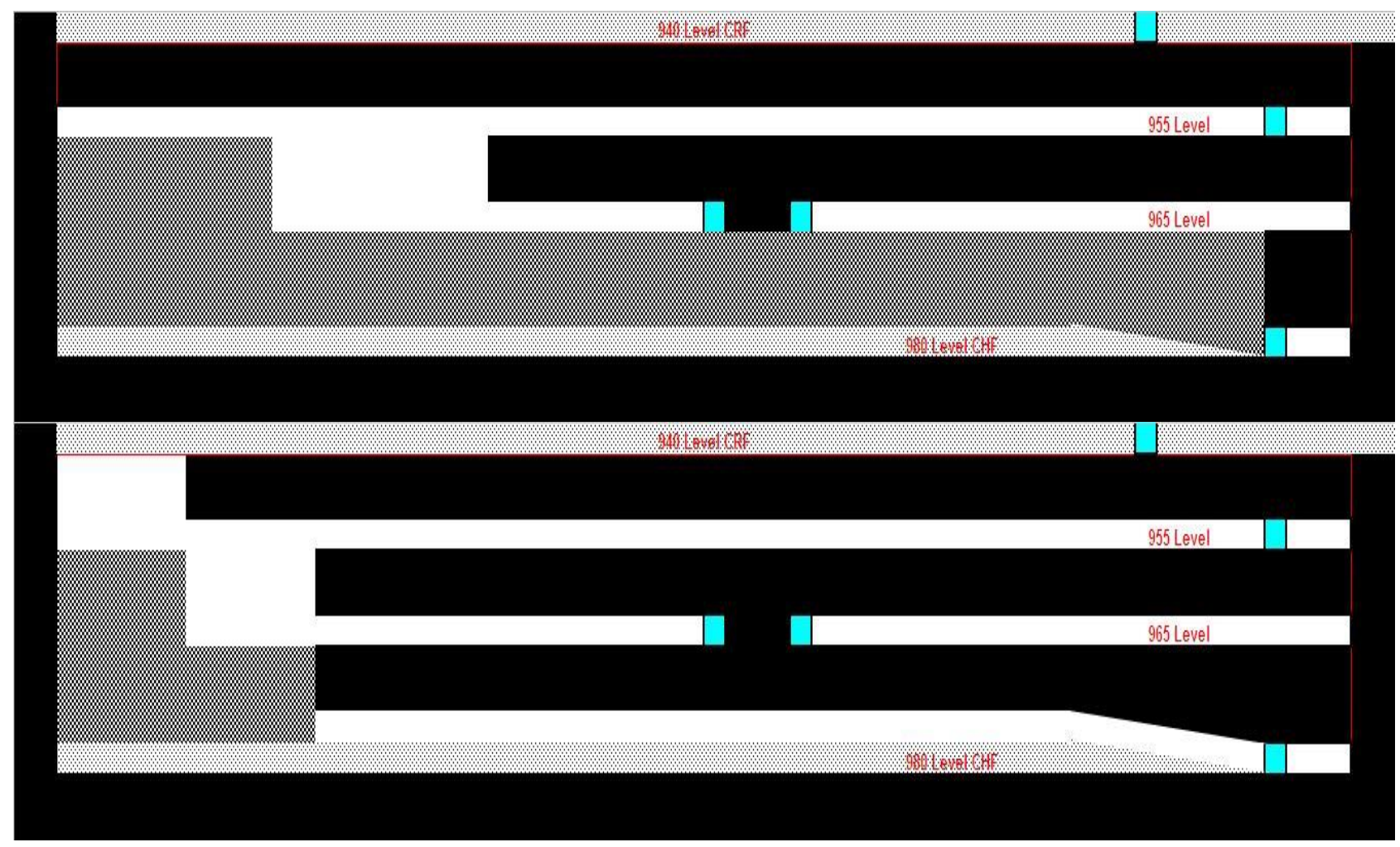

Figure 3 Modified Avoca stoping sequence mines in a standard and checkerboard pattern ( $\mathrm{ight}$ grey = cemented fill, dark grey = waste rock backfill, white = void) 


\section{3. 2 Western Method stoping}

The Anzac Day tragedy was the catalyst for the development of innovative mining methods that had little or no previous history. A key finding of the Case for Safety was that no further personnel access would be permitted in sill drives accessing ore blocks in the West Zone of the mine which had previously been developed in anticipation of extraction by Modified Avoca stoping, whether or not they incorporated the checkerboard initiative (Scott and Reeves, 2007). The solution to the operational dilemma posed by the prohibition of access by personnel was the development of Western Method stoping.

There is no argument that the Western Method was expensive and onerous to implement. Hills et al. (2008) described the method in some detail, but essentially it comprised the following steps:

1. Every existing sill drive was duplicated by a footwall drive at a minimum stand-off distance of $6 \mathrm{~m}$.

2. The footwall drive was reinforced with a dynamic upgrade such that it could withstand a seismic event of maximum magnitude $M_{L} 2.5$ at a distance of $10 \mathrm{~m}$ with a factor of safety of 1.5.

3. A nominal $20 \mathrm{~m}$ strike length stope (approximately $2,000 \mathrm{t}$ ) was drilled using rings of fanned holes from the footwall drive.

4. The stope was blasted in a horizontal chevron pattern utilising the existing sill drive as the free face using rapid electronic initiation. No slot rise was required.

5. The stope was mucked using tele-remote controlled loaders.

6. The resulting excavation was surveyed using a remotely operated laser scanner.

7. The stope was backfilled from the sill drive above using tele-remote loaders.

8. The process was repeated for the next stope, sequenced using the checkerboard initiative.

The Western Method stoping arrangement is illustrated in Figure 4A.

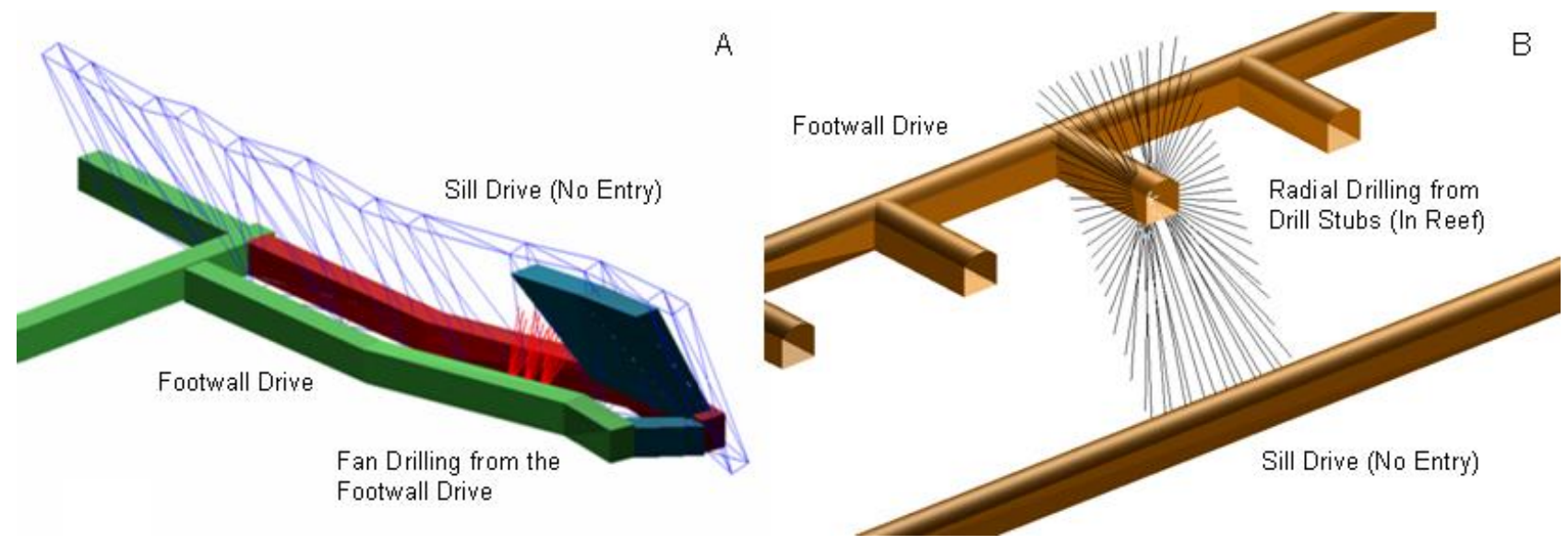

Figure 4 Drawings illustrating (A) Western Method stoping, and (B) Radial-in-Reef stoping

\section{3. 3 Radial-in-Reef stoping}

Where sill drives had already been developed prior to Anzac Day 2006, the Western Method was the only acceptable compromise that met the requirements of the Case for Safety and ensured that no ore was sacrificed. Radial-in-Reef (RiR) stoping (Goddard and Hills, 2011) maintained the tenets of the Case for Safety despite a significant decrease in the amount of development required for each tonne of ore extracted. Complete stoping block heights were comparable to the previously stoped blocks at 38-42 m. A précis of the method for a given stoping block included the following:

1. Complete mining of a single sill drive at the base of the stoping block.

2. Mine a footwall drive at the mid-height of the stoping block at a nominal stand-off of $17 \mathrm{~m}$ and mine stub crosscuts into the orebody on $20 \mathrm{~m}$ centres. 
3. The footwall drive and stub crosscuts were reinforced with a dynamic upgrade such that it could withstand a seismic event of maximum magnitude $\mathrm{M}_{\mathrm{L}} 2.5$ at a distance of $10 \mathrm{~m}$ with a factor of safety of 1.5 .

4. A nominal $20 \mathrm{~m}$ strike length stope (approximately $6,000 \mathrm{t}$ ) was drilled from the stub crosscut using radial rings of holes in the plane of the reef.

5. The stope was blasted in four quadrants to a bored slot rise with a very low void ratio using rapid electronic initiation.

6. The stope was mucked using tele-remote controlled loaders.

7. The resulting excavation was surveyed using a standard cavity monitoring laser from the stub crosscut.

8. The stope was backfilled from the stub crosscut using standard loaders with tele-remote loader top-up as required.

The RiR stoping arrangement is illustrated in Figure 4B.

\subsection{Downho/e Avoca stoping}

The RiR stoping method was a significant operational and financial improvement over the Western Method, but if not required, remained an onerous option. The Case for Safety did not rule out entry stoping methods provided an appropriate analysis of expected rock mass conditions and seismic response was carried out and results were found to be acceptable. Such an analysis was undertaken to determine whether downhole Avoca stoping could be adopted in the West Zone, specifically beneath a substantial crown pillar. Avoca stoping itself needs no explanation, but the circumstances of its use were prescribed:

1. A significant crown pillar of at least $25 \mathrm{~m}$ was required beneath any previous stoping.

2. The sill drive from which drilling was reinforced with a dynamic upgrade such that it could withstand a seismic event of maximum magnitude $M_{L} 2.5$ at a distance of $10 \mathrm{~m}$ with a factor of safety of 1.5 .

3. Extraction of ore on the lower sill drive was by tele-remote controlled loader.

4. There was no access on the lower sill drive by personnel within $50 \mathrm{~m}$ of the stope brow at any time.

Restrictions on the use of the method meant that it was only available for bottom up stoping, and if remaining crown pillars were to be extracted, then RiR stoping would be required.

\section{Management of the geomechanical environment}

Management of the geomechanical environment at the Tasmania Mine has been a key component of an overarching safety management system since the commencement of modern mining operations in the late 1990s. Initially the focus was on kinematic stability of the blocky rock mass, with a particular focus on the development of life-of-mine infrastructure (Hills, 1997). The likelihood of seismically active conditions, particularly in the West Zone of the mine, was anticipated in early development of the mine. Core disking was common in deeper resource definition diamond drill holes, and a desk-top study comparing rock mass characteristics to stress measurement data gathered from other sites across Tasmania indicated a trigger depth for seismicity in the most susceptible strata of the Salisbury Hill Formation at $700 \mathrm{~m}$ or so below surface. Ultimately, strainbursting was first encountered during the development of 760 Level in late 2002. The onset of seismicity was rapid, and a number of measures were put in place to manage it. These and other procedures and protocols developed for the management of the geomechanical environment are contained in or referenced through the Ground Control Management Plan (GCMP). 


\section{1 Safe Work Procedures}

Safe Work Procedures (SWPs) had been developed for all activities undertaken at the Tasmania Mine. A given SWP could either be developed from instructions provided by a supplier for a particular tool or piece of equipment, or it could be developed through a process mapped risk assessment incorporating external research where appropriate. Regardless of its genesis, each SWP is specific to the particular conditions and circumstances extant at the Tasmania Mine. In excess of 30 SWPs specifically relate to management of the geomechanical environment at the Tasmania Mine.

\section{2 Ground Control Management PIan}

Work began on the development of a GCMP in 2004. The first draft (Version A) was completed in February 2005. The document evolved rapidly to encompass as much detail of the geomechanical management of the Tasmania Mine as possible, and make that information available in concise form to the entire workforce. Version B followed in June 2005, Version C in September 2005 and Version D, although it was never formally implemented, in March 2006. Following the rockfall accident of April 2006, production at the Tasmania Mine was suspended pending a complete review of operational procedures. The focus was firmly on geomechanics, but every aspect of the operation, including those aspects which did not involve the underground mine, were process mapped and risk assessed before production resumed in September 2007. The GCMP was revised on three occasions during that period to reflect the developments of the Case for Safety process. Version $E_{1}$ was completed in December 2006, Version $E_{2}$ in April 2007, and Version $E_{3}$ in September 2007. Version F was completed in March 2009 and Version G in October 2010.

The GCMP is specific to the Tasmania Mine, but was modelled on the recommendations contained in published documents including Minerals Industry Safety Handbook (Anon, 2002), Management of Rockfall Risks in Underground Metalliferous Mines (Potvin and Nedin, 2003) and GCMPs completed at and made available by several unrelated mining operations elsewhere in Australia. The GCMP has been audited regularly, with external input from various recognised industry consultants for Versions $A-E_{3}$. Version $F$ was benchmarked against GCMPs from other Tasmanian mines by the local regulator, Workplace Standards Tasmania (WST) (Tunstall, 2010). Most recently, a formal external audit of Version G was undertaken by Sharrock (2010). The latter audit compared the Tasmania Mine GCMP to WADPI (1997) in particular, and as such, benchmarked it against a seminal document in the establishment of the GCMP concept.

The Tasmania Mine GCMP does not prescribe specific work practices. Rather, it provides a framework whereby the geomechanical environment is managed with the aim that instances and effects of ground instabilities are eliminated or reduced to a level as low as reasonably practicable by the following mechanisms:

1. Outlining a systematic approach to ground control.

2. Describing the process for the reporting and communication of geotechnical hazards.

3. Outlining the process and providing guidelines for the prediction, identification, monitoring, assessment and control of changes in the ground conditions.

4. Providing guidelines for the change management in the event that a hazard has been identified.

The GCMP references the SWPs extensively. It includes a series of Trigger Action Response Plans (TARPs), and provides a number of flow charts, which may be used by all personnel to manage geotechnical hazards. It also includes summary geotechnical information. The GCMP is available as a reference to all personnel with copies kept in all offices and underground crib rooms.

\section{$4 \quad$ Measurement, monitoring, modelling and observation}

Collection and interpretation of data from the rock mass at the Tasmania Mine has been extensive. Stress measurement, seismic monitoring and numerical modelling commenced from the onset of seismicity in 2003-2004. Extensive instrumentation commenced with the resumption of production activities in 2007. 
Programmes of rock property testing and rock mass classification have been undertaken regularly as required. The data obtained has provided the basis for managing seismicity over the past decade.

\section{1 Stress measurement}

Measurements of the virgin stress condition at the Tasmania Mine were undertaken on four occasions as the depth of the mine increased. In addition to the initial programme undertaken in 2003 with measurements at 400 Level, 710 Level, 750 Level and 880 Level (O'Toole and Mawdesley, 2004), measurements were also undertaken at 1080 Level (Walton, 2006), 1090 Level (Hulls et al., 2008) and 1200 Level (Hulls and Walton, 2011). Virgin stress measurements are depicted in Figure 5. A logarithmic relationship of increasing stress magnitude with depth was adopted at the recommendation of Kaiser (2008), following the work of Maloney et al. (2006).

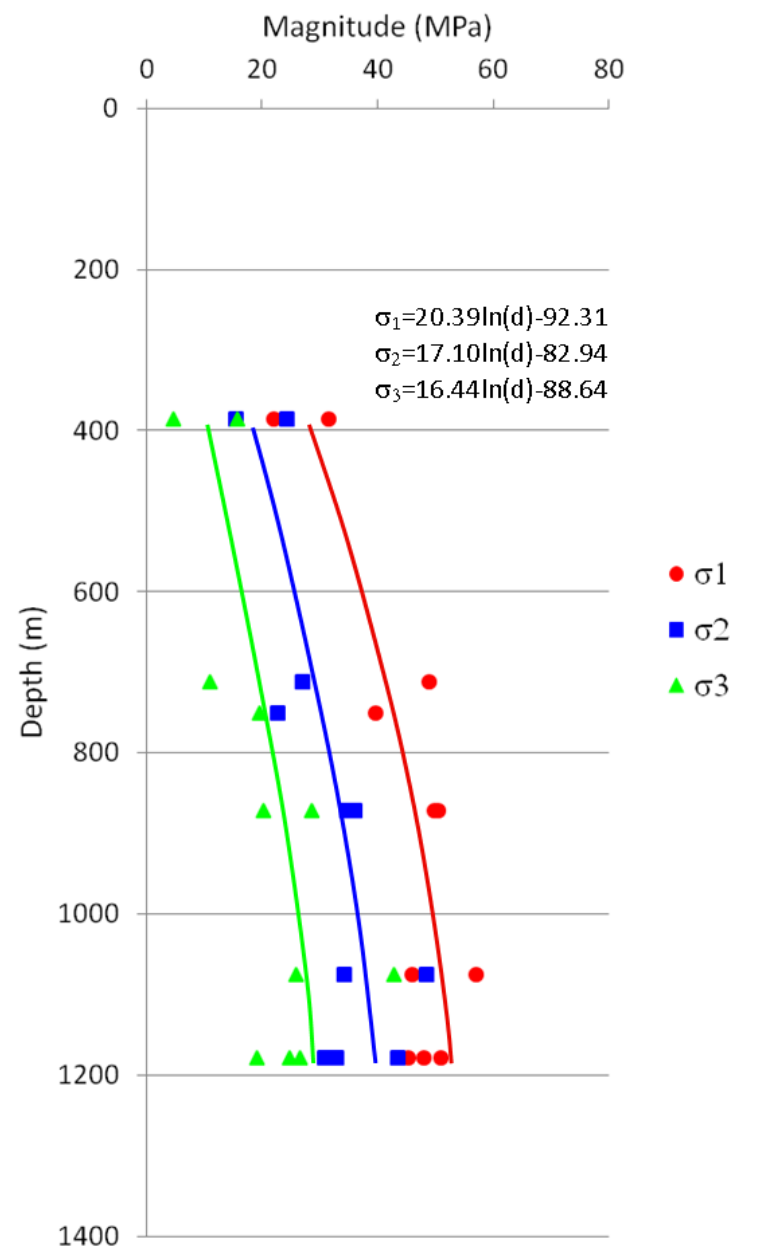

Figure 5 Virgin stress relationship at the Tasmania Mine

Measurements were also undertaken at 955 Level, 1020 Level and 1040 Level (Walton et al., 2009; Hills and Walton, 2010) and 1200 Level (Hulls and Walton, 2011), specifically aimed at measuring the mining induced stress condition, and to allow an absolute determination of stress change at adjacent monitoring sites.

\section{2 Seismic monitoring system}

A temporary seismic monitoring system was commissioned at the Tasmania Mine in April 2004. The system employed an array of six $14 \mathrm{~Hz}$ uniaxial geophones between 840 Level and 925 Level, mounted on the excavation interface. The major benefit of the system was that it provided a background picture of the frequency, nature, magnitude and location of seismic events, and a useful database for preliminary afterthe-fact analysis. However, it was limited by the need to send a recorded disc offsite each week, for 
processing over the course of the following week. As a result, data could be as much as two weeks old before it was available for interrogation by site personnel.

The limitations of the temporary seismic array were quickly apparent. From February 2005, coinciding with the commencement of stoping in the 905 Stoping Block, there was a marked increase in the incidence of seismicity (Figure 6). Turner and Beck (2002) provided a series of guidelines for monitoring early seismicity and thresholds for determining whether mining induced seismicity was likely to be a key driver in the operation of a given mine; in early 2005, the Tasmania Mine was exceeding all of them. The temporary system was replaced with a permanent array in August 2005. Both systems ran in parallel from 2-25 August 2005 to provide a comparison between them. The initial configuration of the permanent array incorporated 12 channels with nine uniaxial and one triaxial geophone between 840 Level and 1040 Level, grouted into boreholes at a depth of $10 \mathrm{~m}$ from the excavation interface. The system was extended on several occasions, and at the time of writing incorporated 29 operational channels, with 14 uniaxial and five triaxial geophones between 400 Level and 1200 Level. The seismic array is illustrated in Figure 7.

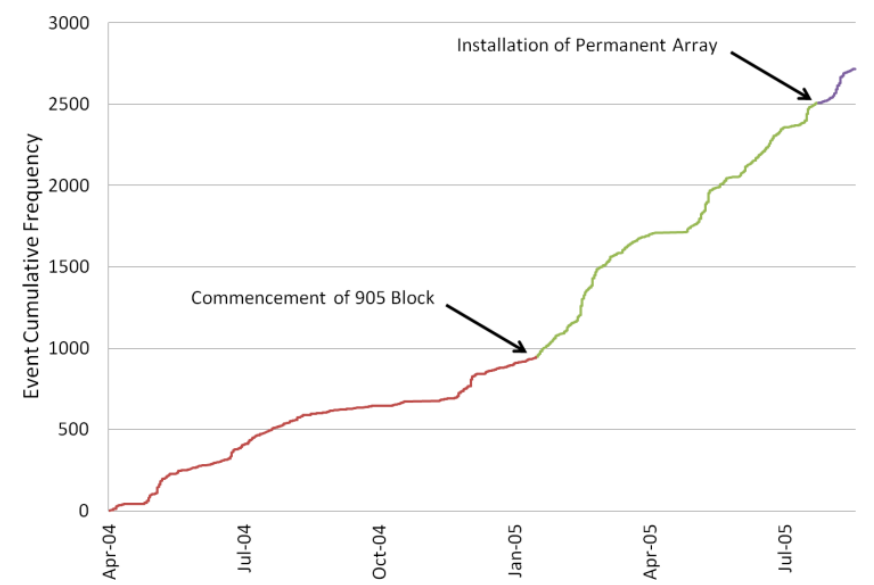

Figure 6 Event cumulative frequency during the operation of the temporary seismic array

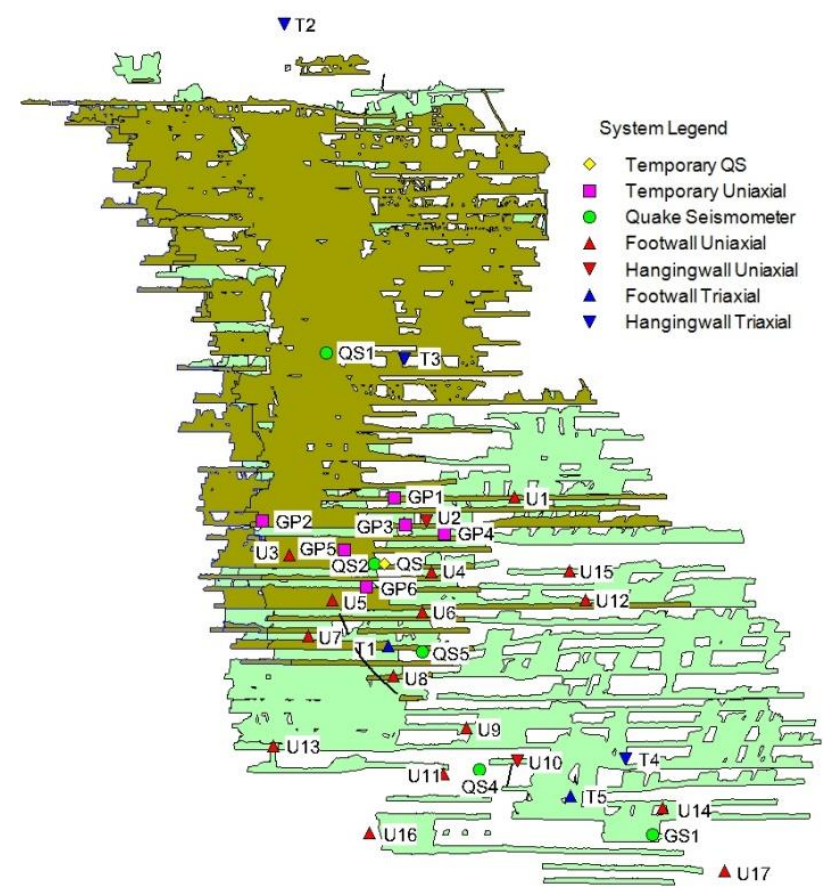

Figure 7 Location of geophones in the Tasmania Mine seismic array. The dark section illustrates the extent of contemporary orebody excavation at the time of installation of the permanent array in August 2005. The Iight colour illustrates additional excavation to October 2011 
The seismic system has changed regularly since the first temporary seismic array was installed in April 2004, with material changes in August 2005 (when the permanent array was installed), September 2007, August 2008, September 2009 and July-August 2011 (Figure 8).

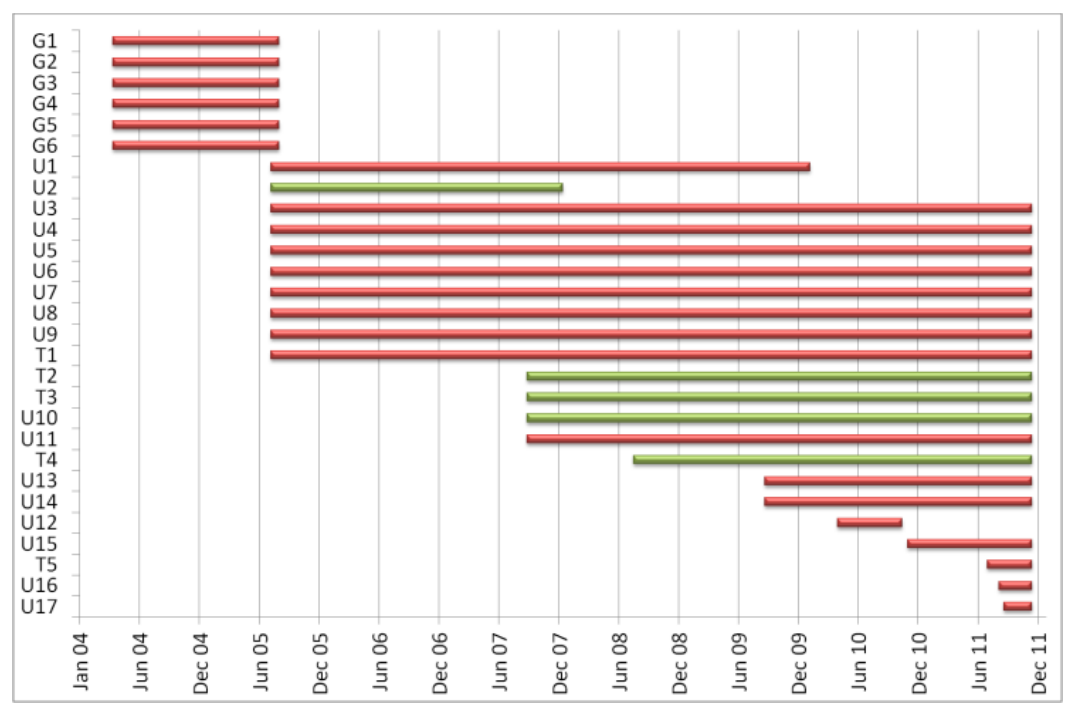

Figure 8 Operation of seismic sensors over time in the Tasmania Mine seismic array (occasional outages not included). Prefixes $G, U$ and $T$ refer to temporary uniaxial, uniaxial and triaxial geophones. With the exception of T2 and T4 which operate at $4.5 \mathrm{~Hz}$, all geophones operate at $14 \mathrm{~Hz}$. Red and green bars indicate footwall and hangingwall installations respectively. U1 was replaced by $\mathrm{U} 12$ and in turn by U15 due to production impacts at the monitoring site

\section{3 Instrumentation}

Geotechnical instrumentation was first installed in the Tasmania Mine in August 2003 as part of the stress measurement programme. On that occasion a single stress change monitoring Hollow Inclusion Cell (HI Cell) was installed at 880 Level. A subsequent stress change monitoring $\mathrm{HI}$ Cell was installed at 1080 Level in January 2006.

Instrumentation was adopted as a key component of geotechnical management generally, and managing seismicity in particular, following adoption of the Case for Safety approach to mining in late 2007 described by Penney et al. (2008). Since that time, in excess of 80 instrument clusters incorporating in excess of 200 separate instruments have been installed in the Tasmania Mine. In addition to $\mathrm{HI}$ Cells, instruments have included vibrating wire stress metres, extensometers and instrumented reinforcement elements in a wide variety of applications.

Instrumentation was concentrated in the West Zone below 700 Level. In a strictly monitoring role, the instrumentation has been used in conjunction with the analysis of seismic data to manage re-entry to excluded areas, after stope blasts and significant seismic events. However, the instrumentation data has also been used to support engineering changes in the operation of the mine. Typically, instruments have been connected to data loggers that could be accessed outside potential exclusion zones and, most recently, from surface.

Almost exclusively, changes to the rock mass manifesting as stress change, rock mass dilation, or increased load on support and reinforcement system have resulted from stope blasts. However, occasional seismic events have been large enough to lead to material change. Figure 9 illustrates the results of stress change monitoring at 1090 Level and clearly links material change to stope blasts. 

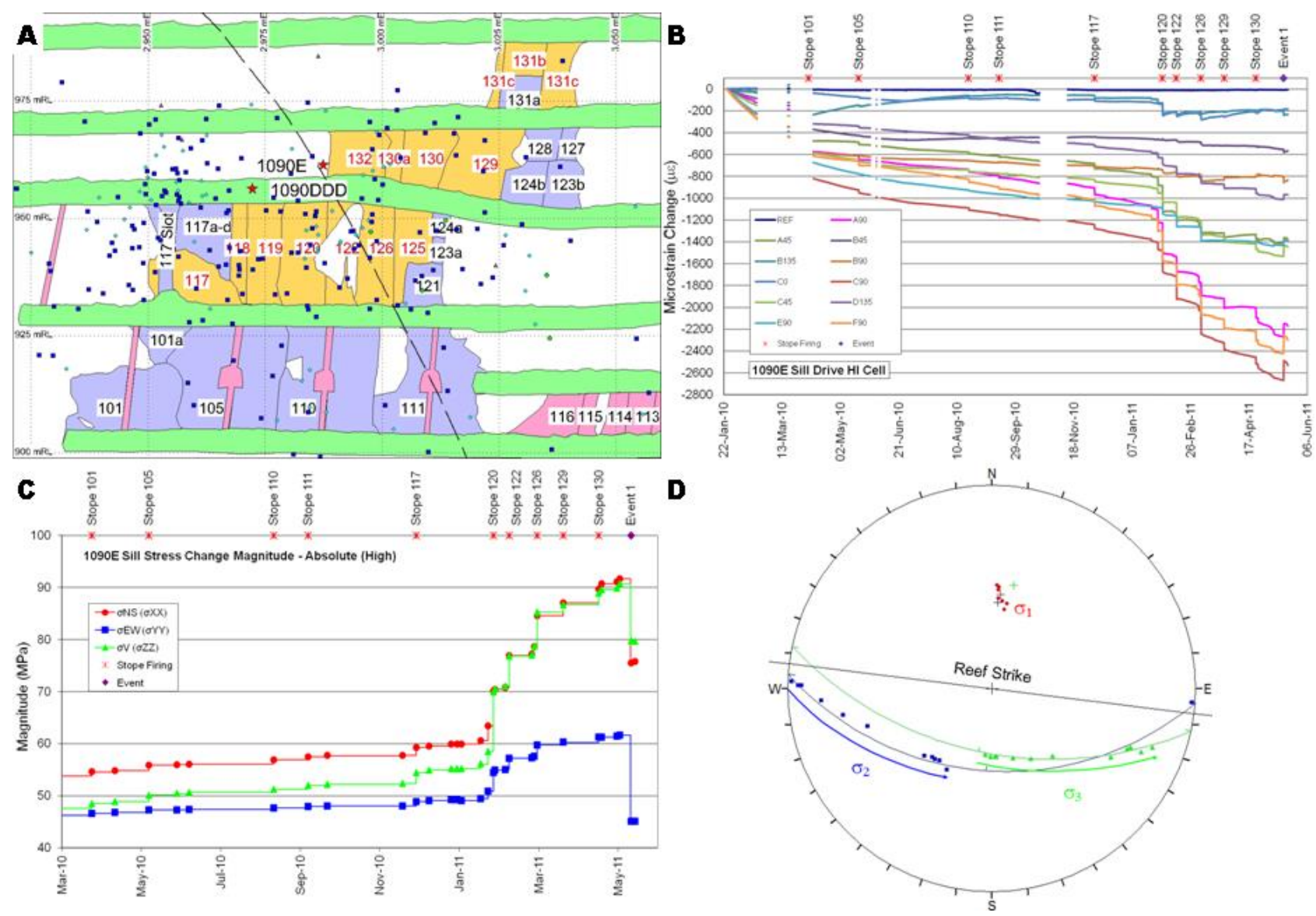

Figure 9 Stress change at 1090 Level was monitored throughout the extraction of a series of stopes in 2010-2011 (A). Micro-strain change recorded by the instrument (B) was most commonly associated with stope blasting. Data was resolved to absolute change in component stresses (C) and the orientation of the stress tensor (D) (Hills and Walton, 2012)

\section{$5 \quad$ Seismic management 2011}

The most critical aspect of seismic management occurs in respect of balancing the safety of the workforce (the importance of which is absolute) against the requirements of production. Ask anyone employed at any mining operation from the general manager to the underground greenhorn to outline the circumstances when production is more important than safety. The answer from every individual will be that there aren't any. This answer is guaranteed every time you ask the question. However, all of these people are frustrated by exclusion and re-entry protocols if a production impact is likely. Everybody knows that without production, their job is on the line. In a marginal operation, such as the Tasmania Mine, that knowledge is acute. Against that background it is absolutely essential that the management of seismicity as perceived by the entire workforce is credible, not only in a forum of geotechnical engineers, but in the boardroom and the crib room as well.

There are two primary aspects to seismic management which lead to frustration. Firstly, there is the installation of ground support and reinforcement. Secondly, there is exclusion from the workplace after blasting or the occurrence of random significant seismic events. Prior to examining those aspects, the following discussion considers the seismicity itself.

\section{1 Seismic history}

It is well known that the number, location and type of sensors will influence the number and range of magnitude of events recorded. Discounting the implication of the foregoing for the moment, Figure 10 is a magnitude versus time plot of seismicity at the Tasmania Mine, since the installation of the permanent 
seismic array in August 2005. It takes no account of the number, location and type of sensors. Moreover, material changes to the seismic array, which over time have resulted in array increased coverage and an increased number of geophones, does not coincide with material changes in the nature and extent of seismicity as recorded.

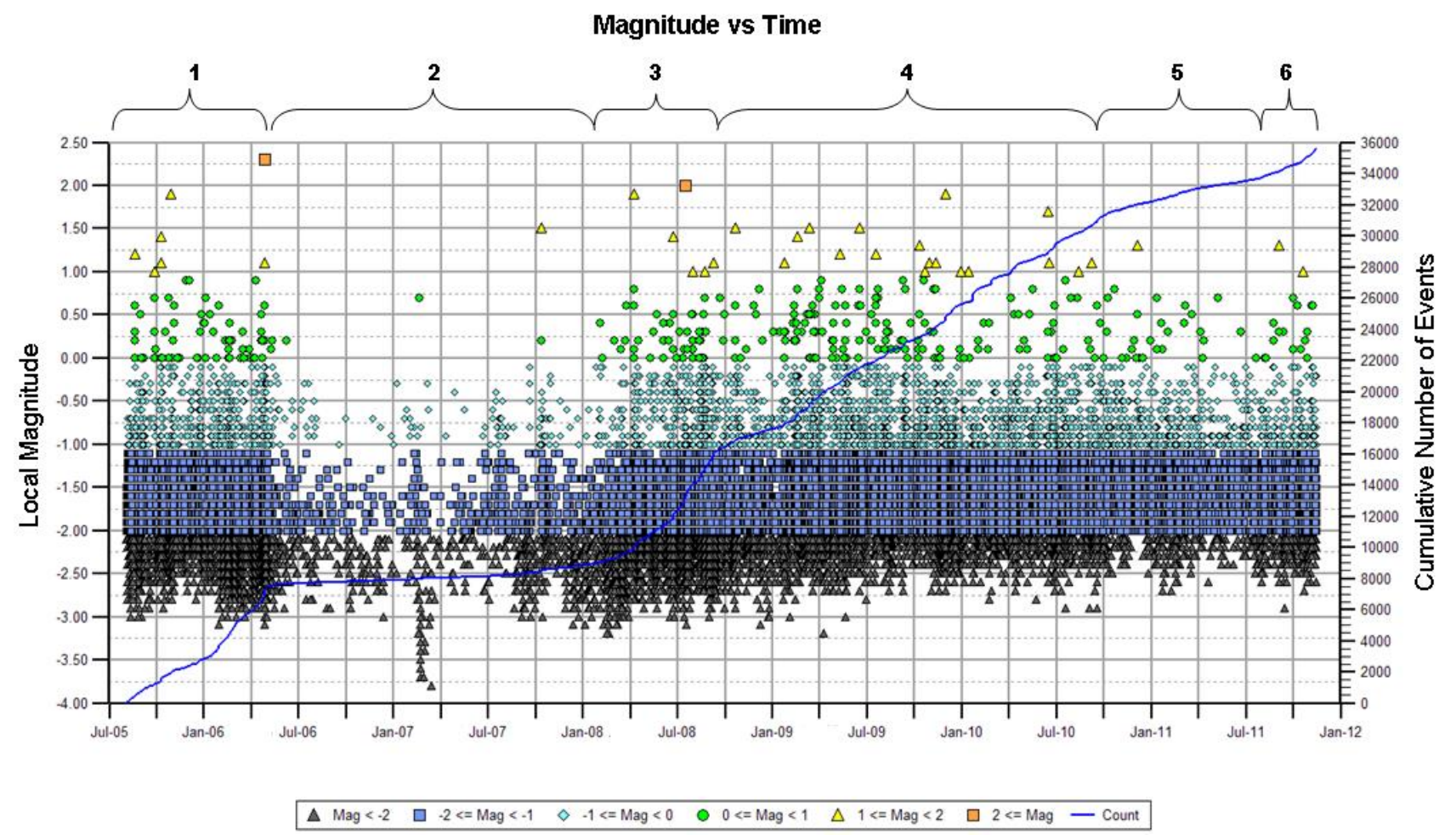

Figure 10 Magnitude versus time plot of seismic history at the Tasmania Mine

Based on the cumulative count, the seismic history of the Tasmania Mine after installation of the permanent array can be divided into six quite distinct periods.

1. The initial period from the installation of the seismic array in August 2005 until the immediate aftermath of the Anzac Day rockfall in April 2006 showed a high intensity of seismicity at an average of 27 events per day. During this period, stoping concentrated in the 905 and 940 Stoping Blocks where mine design incorporated the extraction of $7 \mathrm{~m}$ back to sill stope pillars.

2. Following the Anzac Day rockfall, production at the Tasmania Mine was halted. Although it recommenced in December 2007, little production occurred before February 2008. Previously, ore drive development recommenced in July 2007 leading to slightly increased low level seismicity from that time. A flurry of seismic activity around 20 February 2007 is not well understood, but may be an artefact. Certainly, there is no record of significant seismicity from site personnel. Seismicity during that period averaged 2.5 events per day.

3. From February 2008 until October 2008 production focussed on the extraction of stopes from the 940 and 980 Stoping Blocks extracting a $7 \mathrm{~m}$ pillar. The frequency of seismic events quickly resumed as observed in the lead-up to the Anzac Day rockfall, averaging 26 events per day, and included the second $\mathrm{M}_{\mathrm{L}} \mathbf{2 . 0}$ or greater event at the Tasmania Mine. However, with the implementation of Western Method stoping, and the design protocols of the Case for Safety, the period passed without incident. Western Method stoping represented a material increase in the size of stope blasts from a couple of hundred tonnes to one thousand tonnes or more. It also included the adoption of electronic detonation. However, neither of those changes made a material difference to the occurrence of seismicity. 
4. The material change in production methods, in the period from October 2008 until October 2010, was the increase in level spacing to $15 \mathrm{~m}$ and the consequent increase in pillar thickness to $11 \mathrm{~m}$ in the 1020 and 1080 Stoping Blocks. The impact was a reduction in the rate of seismicity to 21.5 events per day.

5. The fifth period from October 2010 until September 2011 coincided with a concentration of stoping in the relatively aseismic East Zone of the Tasmania Mine. Only one event of $M_{L} 1.0$ or greater occurred during that period. However, there was not "virtually no" seismicity as had been the case during the production hiatus post the Anzac Day rockfall, and an average of 8.5 events per day was recorded.

6. West Zone production resumed in September 2011. This led to an immediate increase in seismicity, but with the introduction of RiR and downhole Avoca stoping, the frequency and magnitude of seismicity was slightly less than that observed during West Zone stoping previously at 20.5 events per day, but not materially so.

Figure 11 illustrates the location of the seismic events over the period discussed. The greater tendency for seismicity to occur in the West Zone of the mine is readily apparent. Consequently, the reduced frequency of seismicity observed during the fifth period of the seismic history is not surprising. In all other cases a progressively lower percentage of rock mass extraction prior to stope blasting would appear to be the key factor. Certainly as each successive period of the seismic history is of the order of $100 \mathrm{~m}$ deeper than the preceding period, intrinsically more benign conditions could not be expected.

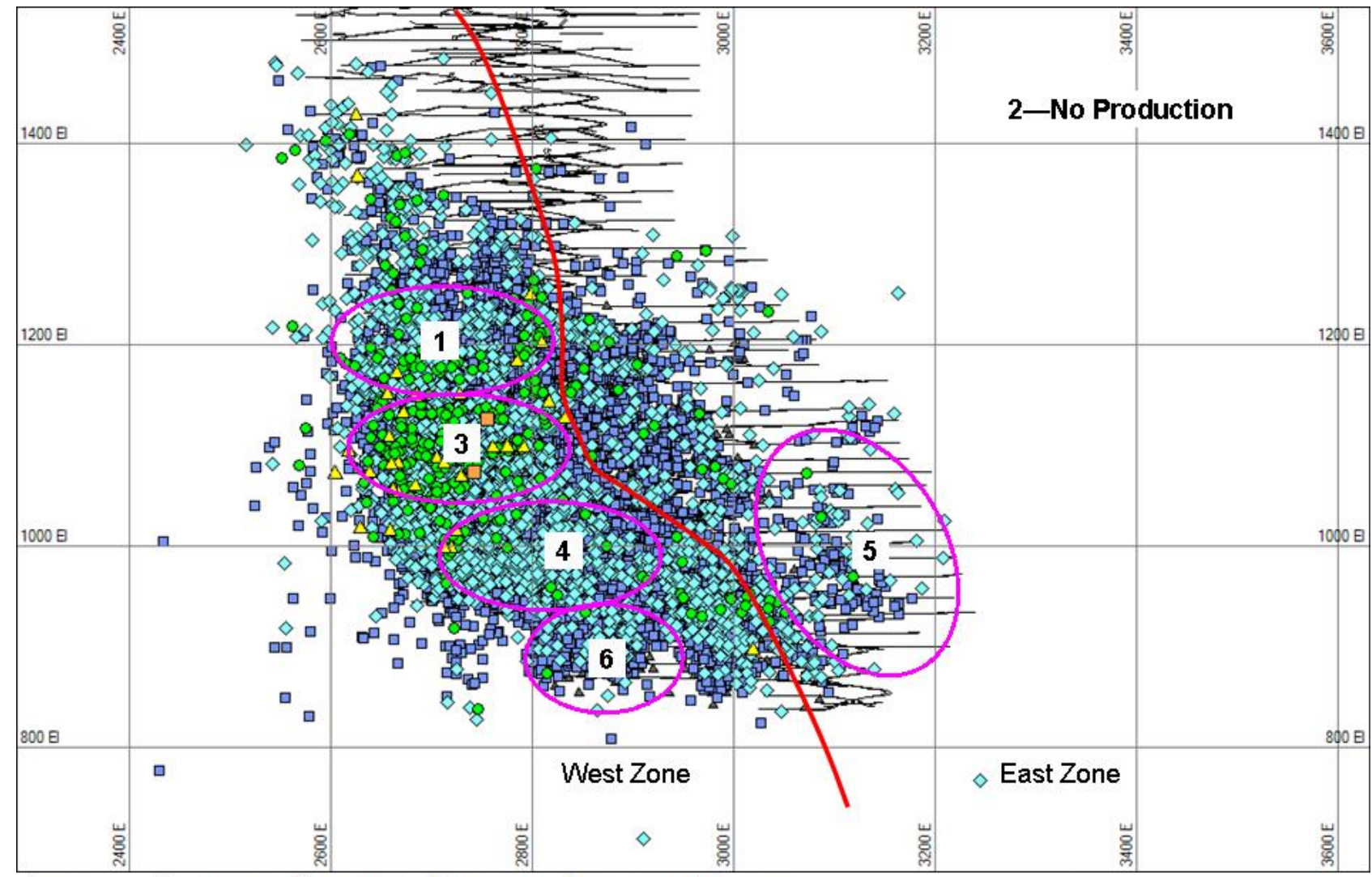

$\triangle \operatorname{Mag}<-2 \quad \square-2<=\operatorname{Mag}<-1 \quad \nabla-1<\operatorname{Mag}<0 \quad 00<\operatorname{Mag}<1 \quad \triangle 1<=\operatorname{Mag}<2 \quad \square 2<=\operatorname{Mag}$

Figure 11 The location of seismic events recorded by the permanent array illustrating core (but not exclusive) production area during each of the six periods of seismic history. The red line represents the boundary of the West Zone 


\section{2 Seismic management challenges}

\subsubsection{Ground support and reinforcement}

It is not intended that this paper includes a detailed précis of ground control and reinforcements protocols and methods developed at the Tasmania Mine. A thoroughly engineered process for the design of ground support and reinforcement at the Tasmania Mine was devised following the protocols of the Canadian Rockburst Support Handbook (Kaiser et al., 1996) and reviewed on site by Kaiser (2008) as part of the Case for Safety process following the Anzac Day rockfall. The methodology employed at the Tasmania Mine has been described in available literature by Scott et al. (2008) and Hills (2009). Suffice to say that the system appears excessive, and the resulting challenge is to ensure that it is installed diligently to the required design and accepted by stakeholders.

The engineering will convince management and technical staff of the validity of the design, provided the support and reinforcement requirement is credible. If the design methodology demands an unreasonable density of dynamic cable bolts, the exercise demonstrates that the design is not practicably supportable. It is essential that such situations are recognised.

The underground workforce is another matter. At the Tasmania Mine, the workers undertaking the development and installing the ground support and reinforcement in the development phase are not the workers charging and mucking the stopes in the production phase. That is not to suggest a lack of duty of care. Rather, it is a necessity to ensure that all personnel are appraised of the consequences of their actions in circumstances which they themselves might not experience. The whole workforce requires regular presentations focussing on real examples from their own workplace, how the ground support and reinforcement performs.

As an example, Figure 12 illustrates static and dynamic cable bolts installed side-by-side close to a stope brow. Following the occurrence of a blasting-induced dynamic load on the support system, the older static support (yellow circles) appeared undamaged (Figure 12A). Dynamic cables closer to the blasting front (green circles) had lost their plates (Figure 12B). Those further back (red circles) had substantially deformed plates. An extensometer in the middle of the reinforcement array (blue circle) suggested that the rock mass may have failed at a depth of fracture of approximately $2 \mathrm{~m}$ (Figure 12C). The immediate expectation was that the static cables had failed at about $2 \mathrm{~m}$, and indeed they had (Figure 12D). This and a number of other examples have regularly been explained to the workforce at weekly toolbox meetings, as it is essential that everyone understands to ensure that the support is installed as designed using the correct support and reinforcement elements. 


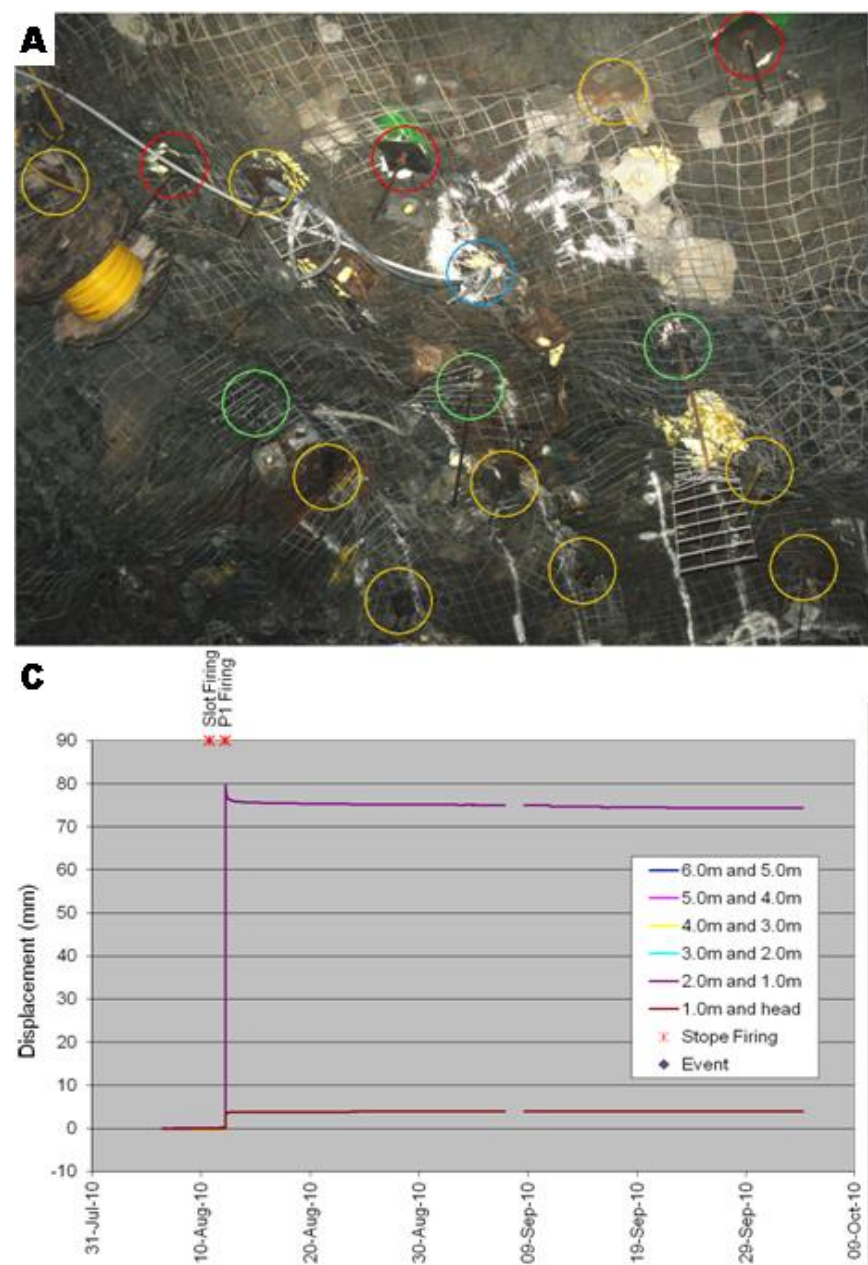

B

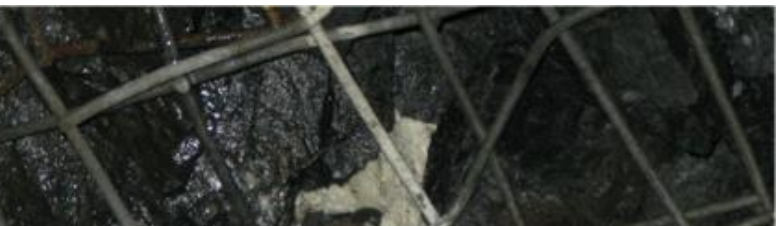

Figure 12 (A-D) The response of static versus dynamic support

\subsection{Exclusion and re-entry}

An ambit exclusion period of 24 hours was adopted for re-entry exclusion following stope blasting and significant seismic events in 2005. Commencing with the installation of the permanent seismic array, analysis of seismic data using the software supplied with the seismic system, and since early 2006 with the addition of MS-RAP ver. 3, has been used to assist in reinforcing the exclusion and re-entry policy, and refining it where possible. The basis of exclusion and re-entry analysis practiced at the Tasmania Mine is the Omori chart (Figure 13). It is used in conjunction with Apparent Stress History and Energy Index / Cumulative Apparent Volume charts to assess whether re-entry is appropriate. 


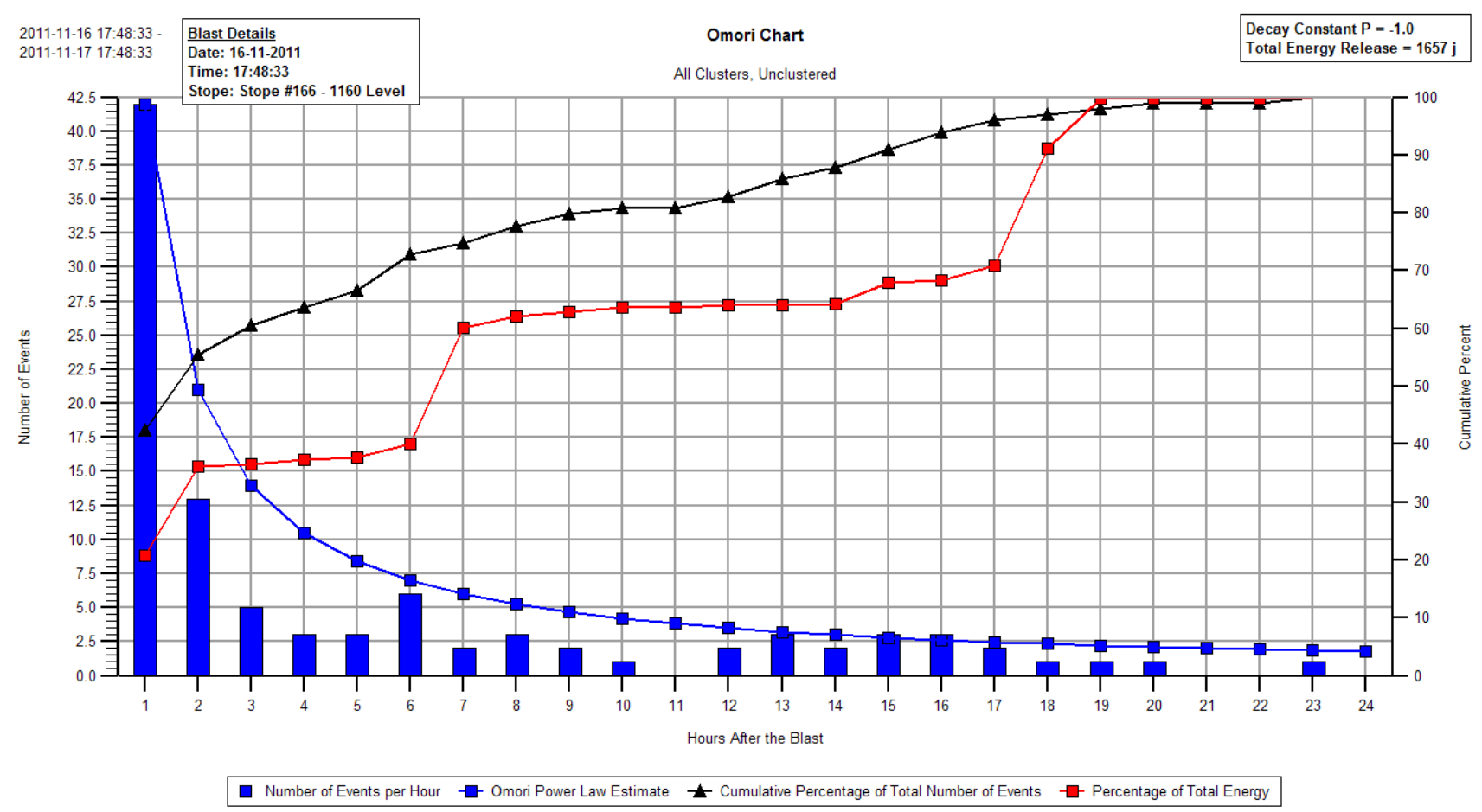

Figure $13 \mathrm{Classic}$ Omori chart following a stope blast

Kari (2009) determined that in most instances, based purely on analysis of seismic data, that 24 hours was excessive. Penney (2011) reiterated that finding, and proposed a series of guidelines based on energy release, event rate and event micro-threshold magnitude to manage post blast re-entry.

It is well beyond the scope of this paper to outline the process established. Penney (2011) rightly stated that the guidelines he established were specific to the Tasmania Mine and that variances in seismic response and rock material properties may render the guidelines inappropriate elsewhere. Consequently, the reader is directed to the source document for further explanation.

Instrumentation can also play a role in determining the suitability of re-entry after a stope blast or significant seismic event. In particular, data trends readily show when equilibrium has been re-established.

The key requirement of an exclusion and re-entry protocol is once again related to its credibility to the entire workforce. It is critical to managing exclusion and re-entry that operators do not sit idly by or get redeployed to alternative tasks, or that managers see a lack of productivity when exclusion is not necessary, because there will inevitably be times when the geotechnical engineer needs to extend an exclusion when the reasons might not be as apparent as ongoing high magnitude seismicity.

\subsection{Ongoing seismic management}

The same tools that are available for managing exclusion and re-entry are used to understand the evolving geotechnical environment. As an example, Figure 14 illustrates the commencement of a new stoping block based around RiR and downhole Avoca stoping equivalent to Period 6 of the seismic history discussed in Section 5.1. The stoping front moved from west to east and the respective stopes were extracted at 1180 Level and 1160 Level as indicated by the arrows.

The increasing concentration of seismicity at the eastern abutment of the advancing stoping front was to be expected, and is manifest in the event count and the constancy of seismicity observed on the magnitude versus time plot (Figure 15). The expectation was that as the stoping front advanced towards the east, the impact of stress change would also advance towards the east. That was the observation (Figure 16). The further expectation was that Pillar 2/3 (site M2 in Figure 14) should have passed into stress shadow with the blasting of $1160 \mathrm{P} 3$, and that also occurred. At the time of writing, monitoring sites M1 and M3 were 
situated in the stoping abutment and site M3 was well removed from the influence of stoping. That too is apparent in the data.

The practice at the Tasmania Mine is to gather sufficient high quality seismic and geotechnical monitoring data such that the assumptions surrounding rock mass behaviour that could reasonably be assumed are in fact confirmed. The information so gathered is readily able to be used in the calibration of numerical models ahead of future development and production. The view is also taken, that if sufficient data supports and confirms reasonable engineering expectation, then data which does not provide a clear lead-indicator is of future concern.

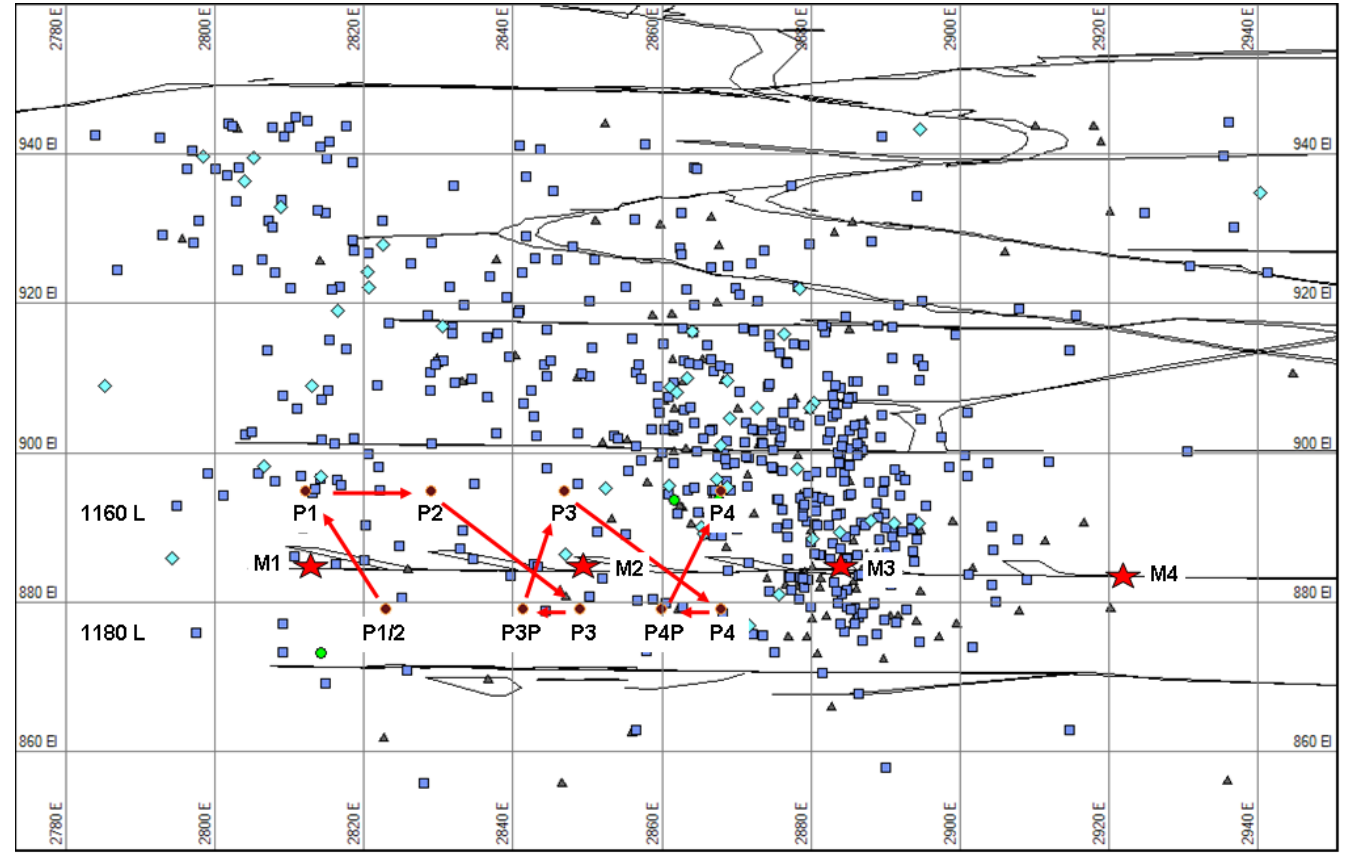

$\Delta$ Mag $<-2 \quad \square-2<=\operatorname{Mag}<-1 \quad \diamond \cdot 1<\operatorname{Mag}<0 \quad 00<=\operatorname{Mag}<1 \quad \triangle 1<=\operatorname{Mag}<2 \quad \square 2<=$ Mag

Figure 14 Stoping sequence and seismicity during Period 6 of the seismic history to November 2011. Note the relative position of footwall monitoring sites M1-M4

\section{Magnitude vs Time}

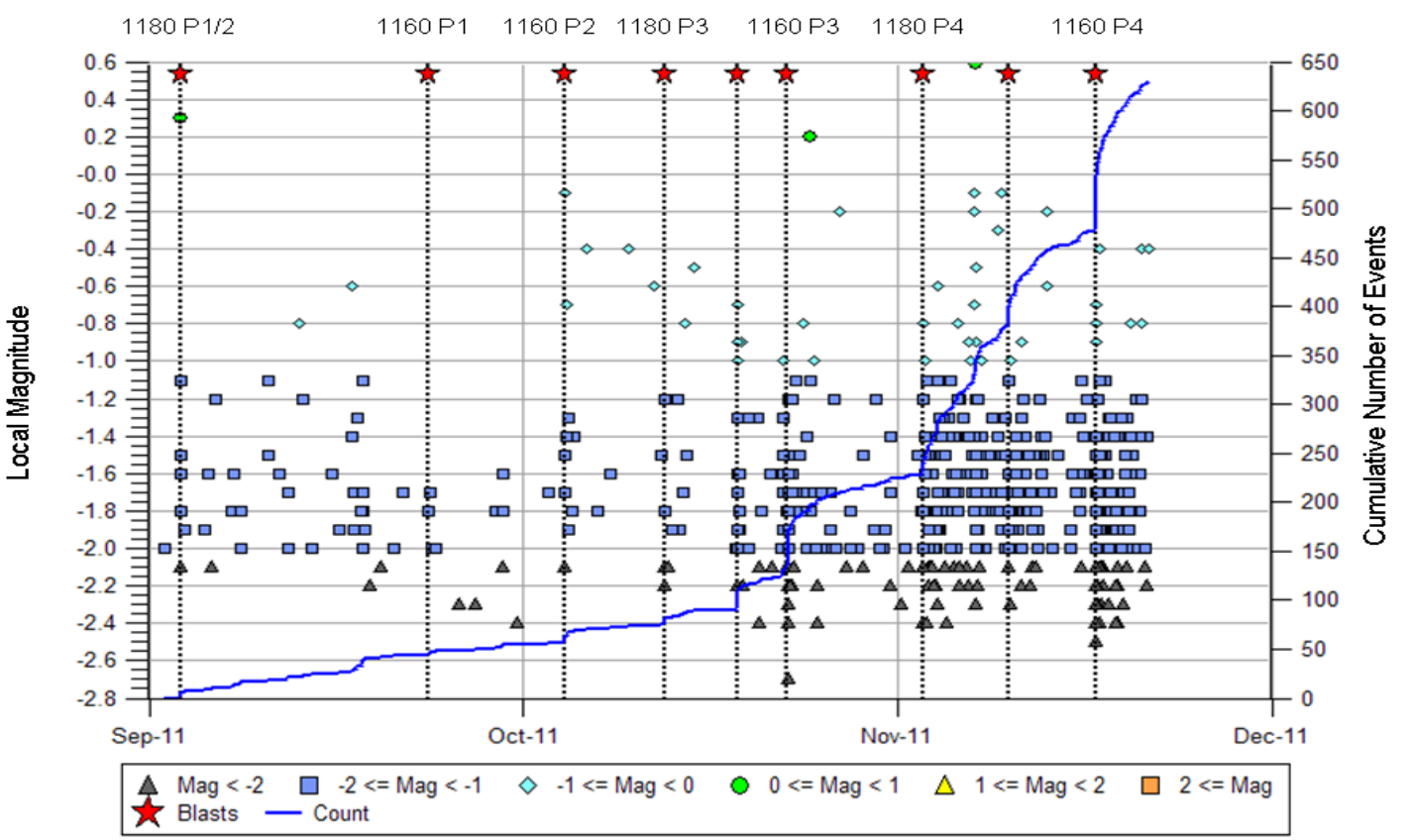

Figure 15 Magnitude versus time plot for point 6 of the seismic history 

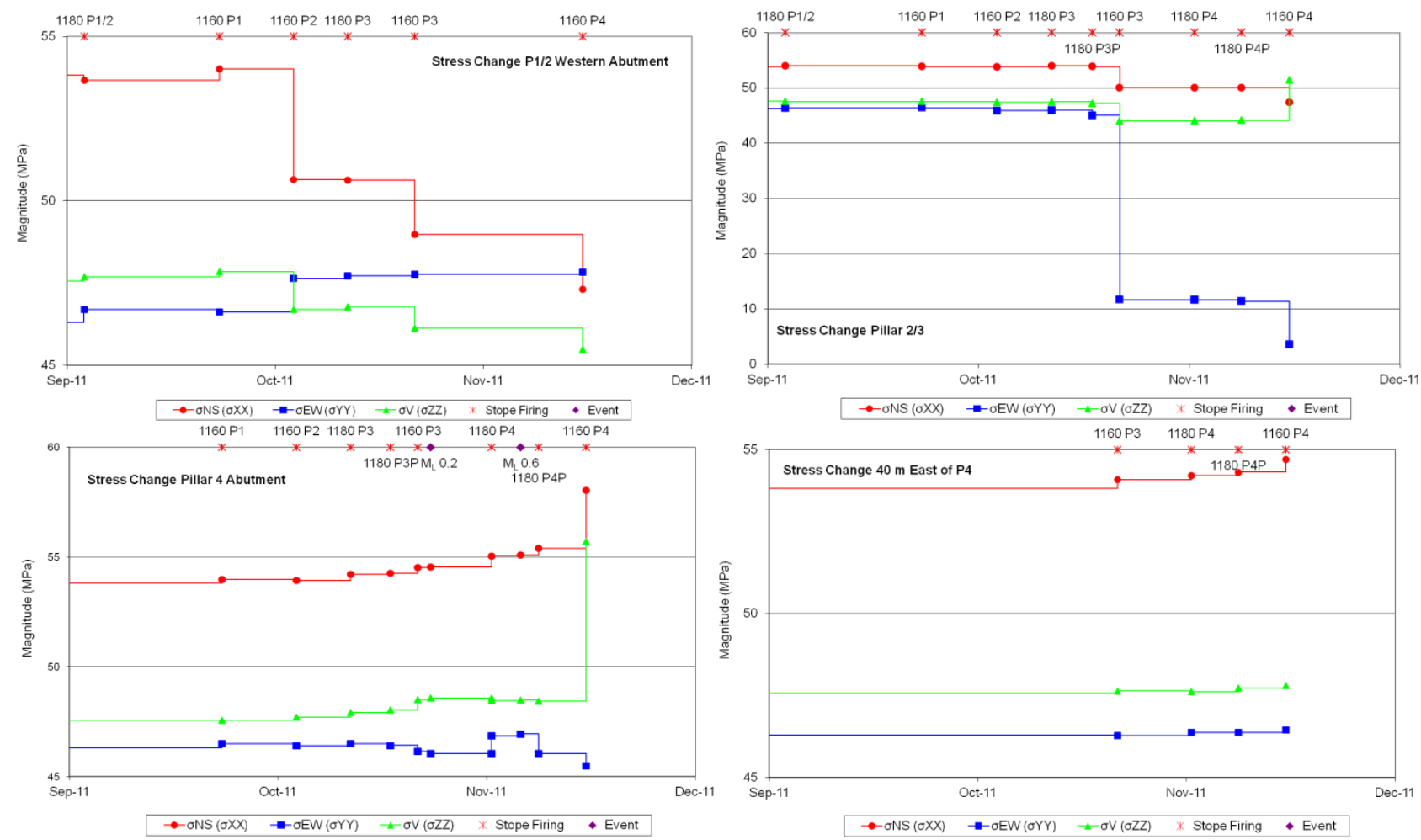

Figure 16 Stress change monitoring site in the 1160 Level footwall drive illustrating progressive stress change as the stoping front advances to the east

\section{Conclusion}

Management of seismicity at the Tasmania Mine was previously described by Hills and Penney (2008) and it was not the author's intention to reiterate that description here. Management of seismicity at the Tasmania Mine did not commence in response to a statutory notice served on the Company by WST in response to the Anzac Day rockfall. However, the WST requirements did precipitate a comprehensive and unprecedented review of seismic management practices at the Tasmania Mine.

1. Previously untried mining methods were devised to limit the exposure of personnel to areas of identified high seismic risk.

2. Protocols for fully engineered ground support and reinforcement were designed.

3. The use of seismic and rock mass monitoring and modelling was enhanced.

4. The scope of the GCMP was expanded.

5. The workforce at all levels was engaged to ensure a high level of understanding and compliance with overall process.

None of the geotechnical engineering applied to the Tasmania Mine is new. The novelty is in the application of that engineering to the real world of a producing mine. New mining methods were developed, new procedures were implemented, and a very high level of engagement with the workforce at all levels was sought and received.

Nothing in the foregoing paper, and indeed nothing that has occurred at the Tasmania Mine either before or since Anzac Day 2006 is a guarantee. There will always be risk. The best that can be achieved, so long as wealth is sought from deep seismically active mines, is to reduce the risk in line with the principle of As Low As Reasonably Practicable (ALARP). It would be unfortunate to believe that the position has been reached so long as any risk remains. 


\section{Acknow l edgements}

The author wishes to thank the management of BCD Resources (Operations) NL for permission to publish this keynote paper.

\section{References}

Anon. (2002) Minerals Industry Safety Handbook, New South Wales Department of Mineral Resources, Part 4, pp. 64-74.

Falmange, V. and Simser, B.P. (2004) Performance of rockburst support systems in Canadian Mines, in Proceedings Fifth International Symposium on Ground Support, Ground Support in Mining and Underground Construction, E. Villaescusa and Y. Potvin (eds), 28-30 September 2004, Perth, Australia, Australian Centre for Geomechanics, Perth, pp. 313-318.

Goddard, R. and Hills, P.B. (2011) The development of 'Radial-in-Reef' stoping at the Tasmania Gold Mine, Beaconsfield, Tasmania, in Proceedings Eleventh Underground Operators Conference 2011, The Australasian Institute of Mining and Metallurgy, Melbourne, pp. 55-62.

Grimstad, E. and Barton, N. (1993) Updating the Q system for NMT, in Proceedings International Conference on Sprayed Concrete, Norwegian Concrete Association, Oslo, pp. 44-66.

Hills, P.B. (1997) A Review of Geomechanics Applied to Re-opening of the Beaconsfield Gold Mine, in Proceedings Third International Mining Geology Conference, The Australasian Institute of Mining and Metallurgy, Melbourne, pp. 41-48.

Hills, P.B. (2009) Ground Support Protocols at Beaconsfield Gold Mine, Tasmania, in Course Proceedings Advanced Ground Support in Underground Mining Seminar (Course No. COR0910), 11-13 November 2009, Perth, Australia, Australian Centre for Geomechanics, Perth, Section 13.

Hills, P.B., MacDonald, G., Nero, L. and Mueller, A.M. (2001) Beaconsfield Gold Mine - Tasmania Reef, Structure and setting of Proterozoic and Palaeozoic rocks in the Tamar region, Northern Tasmania, Geological Society of Australia Specialist Group in Tectonics and Structural Geology - Field Guide No. 9, A.R. Reed (ed.), Geological Society of Australia, Sydney, pp. 57-75.

Hills, P.B., Mills, J., Penney, A.R. and Arthur, S. (2008) The development and implementation of a fully remote stoping method at Beaconsfield Gold Mine, Tasmania, in Proceedings of the Narrow Vein Mining Conference 2008, The Australasian Institute of Mining and Metallurgy, Melbourne, pp. 199-206.

Hills, P.B. and Penney, A.R. (2008) Management of seismicity at the Beaconsfield Gold Mine, Tasmania, in Proceedings of the Tenth Underground Operators Conference 2008, The Australasian Institute of Mining and Metallurgy, Melbourne, pp. 157-170.

Hills, P.B. and Walton, R.J. (2010) Calibrated geotechnical measurement to provide a quantitative understanding of rock mass conditions at Tasmania Gold Mine, Beaconsfield, Tasmania, in Proceedings of the Second Australasian Ground Control in Mining Conference 2010, The Australasian Institute of Mining and Metallurgy, Melbourne, pp. 149-158.

Hills, P.B. and Walton, R.J. (2012) Continued observations of rock mass behaviour in response to stoping at the Tasmania Mine, Beaconsfield, Tasmania, in Proceedings of the Third Narrow Vein Mining Conference 2012, The Australasian Institute of Mining and Metallurgy, Melbourne.

Hulls, I., Smith, J. and Walton, R.J. (2008) Tasmania Mine - 1090 Level Stress Measurements, Coffey Mining Report No. MINENHIL00130AA, unpublished.

Hulls, I. and Walton, R.J. (2011) Tasmania Mine - 1200 Level stress measurements August 2011, Mining One Pty Ltd Report No. $P: \backslash 1615 \_G \backslash 2899$, unpublished.

Kaiser, P.K. (2008) Geomechanics and Ground Support Review - Beaconsfield Gold Mine, MIRARCO, Sudbury, unpublished.

Kaiser, P.K., McCreath, D.R. and Tannant, D.D. (1996) Canadian Rockburst Support Handbook, Geomechanics Research Centre, Sudbury.

Kari, N. (2009) Seismic analysis - Beaconsfield Gold Mine, Tasmania, Allstate Explorations NL, Internal Report, unpublished.

Maloney, S., Kaiser, P.K. and Vorauer, A. (2006) A Reassessment of in situ stresses in the Canadian Shield, 41st U.S. Rock Mechanics Symposium, Golden, $9 \mathrm{p}$.

O'Toole, D.A. and Mawdesley, C. (2004) Virgin stress measurement results and stress management options, Beaconsfield Mine, Tasmania, Coffey Geosciences Report No. Z13149/1-AG, unpublished.

Penney, A.R. (2011) Development of re-entry guidelines and exclusion zones at Tasmania Gold Mine, Master of Engineering Science in Mining Geomechanics thesis, Curtin University of Technology, Kalgoorlie, unpublished.

Penney, A.R., Hills, P.B. and Walton, R.J. (2008) The use of geotechnical instrumentation to optimise an engineered mine design at Beaconsfield Gold Mine, Tasmania, in Proceedings Narrow Vein Mining Conference 2008, The Australasian Institute of Mining and Metallurgy, Melbourne, pp. 165-172.

Potvin, Y. and Nedin, P. (2003) Management of rockfall risks in underground metalliferous mines, Minerals Council of Australia, Canberra, $160 \mathrm{p}$.

Scott, C., Penney, A.R. and Fuller, P. (2008) Competing factors in support selection for the west zone of the Beaconsfield Gold Mine, Tasmania, in Proceedings Narrow Vein Mining Conference 2008, The Australasian Institute of Mining and Metallurgy, Melbourne, pp. 173-178.

Scott, C. and Reeves, I. (2007) Geotechnical assessment - resumption of ore production (West Zone), Coffey Mining P/L Report No. HZ00054.01.BY, unpublished.

Sharrock, G. (2010) Peer Review: Ground Control Management Plan - Revision G, UNSW Global Pty Ltd, Sydney, unpublished.

Tunstall, A.M. (2010) Summary of ground control audits at Tasmanian underground metalliferous mines, Workplace Standards Tasmania, Hobart, 5 p unpublished. 
Turner, M. and Beck, D. (2002) Monitoring the onset of seismicity, in Proceedings First International Seminar on Deep and High Stress Mining (Deep Mining 2002), 6-8 November 2002, Perth, Australia, Australian Centre for Geomechanics, Perth, Section 46, $22 \mathrm{p}$.

WADPI (1997) Western Australia Department of Primary Industries. MOSHAB Geotechnical considerations in underground mines guidelines, December 1997, Document No. ZME723QT, Perth.

Walton, R.J. (2006) Tasmania Mine, Tasmania, Virgin rock Stress measurements at 1080 Level, Coffey Geosciences Report No. HZ00024/01-AD, unpublished.

Walton, R.J., Hulls, I. and Penney, A.R. (2009) Mining induced stress measurements and monitoring at 955, 1020 and 1040 Levels Beaconsfield Gold Mine, Coffey Mining Report No. MINENHIL00189AD, unpublished. 